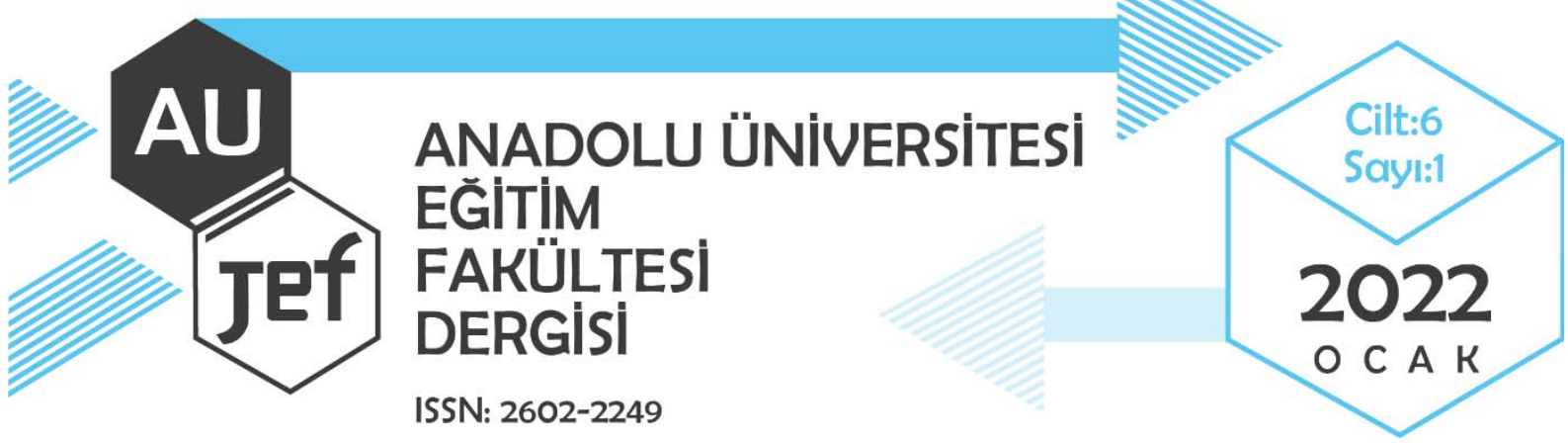

\title{
Eğitimde Teknoloji Entegrasyonu ile ilgili Türkiye’de Yapılan Çalışmaların İncelenmesi
}

\section{Examining the Researches in Turkey on Technology Integration in Education}

Ganime Beyza ARSLAN ${ }^{1}$, Esra KIZILAY ${ }^{2}$, Mustafa HAMALOSMANOĞLU ${ }^{3}$

\section{Makale Türü ${ }^{4}$ Derleme}

Başvuru Tarihi: 30.07 .2021

Kabul Tarihi: 14.01 .2022

Atıf İçin: Arslan, G.B., Kızılay, E. ve Hamalosmanoğlu, M. (2022). Eğitimde Teknoloji Entegrasyonu ile ilgili Türkiye'de Yapılan Çalışmaların İncelenmesi. Anadolu Üniversitesi Eğitim Fakültesi Dergisi (AUJEF), 6(1), 3955.

ÖZ: $\mathrm{Bu}$ araştırmanın amacı, eğitimde teknoloji entegrasyonuna yönelik 2015-2020 yılları arasında yapılan çalışmaları betimsel içerik analizi yöntemi çerçevesinde inceleyerek, alan yazındaki genel eğilimi ortaya koymaktır. Araştırmada 2015-2020 yılları arasındaki eğitimde teknoloji entegrasyonu kavramı üzerine TR Dizin ve YÖK Tez Merkezi'nde yer alan çalışmalara ulaşılarak gerekli şartları sağlayan 56 çalışma incelenmiştir. Çalışmalar araştırmanın türü, araştırmanın yılı, araştırma yaklaşımı, araştırma modeli/deseni, katılımcı büyüklüğü, katılımcı grup türü, veri toplama aracı ve veri analiz yöntemi dikkate alınarak analiz edilmiştir. Araştırma verileri içerik analizi ile analiz edilmiştir. Analizler sonucunda eğitimde teknoloji entegrasyonu konusunun en çok yüksek lisans tezlerinde çalışıldığı belirlenmiştir. Eğitimde teknoloji entegrasyonu çalışmaları son beş yıl içerisinde en çok 2019 yılında yürütülmüştür. Çalışmalarda en fazla nicel araştırma yönteminin kullanıldığı belirlenmiştir. Araştırmada incelenen çalışmalarda en fazla kullanılan desenin durum çalışması olduğu tespit edilmiştir. En fazla çalışılan katılımcı büyüklüğünün 0-100 kişi arasında yer aldığı, katılımcı grup açısından en çok öğretmenlerle çalışıldı̆̆ tespit edilmiştir. Çalışmalarda veri toplama aracı olarak en fazla ölçek kullanıldığı belirlenmiştir. İncelenen çalışmalarda veri analizi açısından daha çok içerik analizi kullanılmıştır. Elde edilen veriler alan yazındaki çalışmalar çerçevesinde tartışılmıştır. Araştırma sonucunda, alan yazın incelemelerinden hareketle teknoloji entegrasyonuna ilişkin gelecek araştırmalara ve uygulayıcılara öneriler sunulmuştur. İlerideki çalışmalarda daha geniş bir zaman dilimindeki ve farklı veritabanlarındaki çalışmalar dahil edilerek, eğitimde teknoloji entegrasyonu çalışmalarına kapsamlı bir bakış sunulabilir. Nitel araştırma yöntemi olay ve olguların daha derinlemesine incelenmesini sağladığı için nitel ve karma yöntemlerin kullanıldığı eğitimde teknoloji entegrasyonuna dair çalışmalar yürütülebilir.

Anahtar sözcükler: Betimsel içerik analizi, Eğitim teknolojileri, Teknoloji entegrasyonu

\footnotetext{
${ }^{1}$ Öğretmen, Taşoluk İmam Hatip Ortaokulu, gbeyzarslan@gmail.com, ORCID:0000-0002-5426-615X

${ }^{2}$ Dr. Öğr. Üyesi, Erciyes Üniversitesi, Fen Bilgisi Eğitimi, eguven@erciyes.edu.tr, ORCID:0000-0001-8329-0186 (Başlica yazar / Corresponding author)

${ }^{3}$ Doç. Dr., Erciyes Üniversitesi, Fen Bilgisi Eğitimi, hamalosmanoglu@erciyes.edu.tr, ORCID:0000-0002-11260268

${ }^{4}$ Makale derleme türünde olduğu için etik kurul izni alınmamıştır.
} 
ABSTRACT: This study uses the descriptive content analysis method to uncover the general trend in the literature by reviewing works on technology integration in education from 2015 to 2020 . In the study, 56 papers on the notion of technology integration in education between the years 2015 and 2020 were investigated by reaching the studies in TR Index and YOK Thesis Center that met the relevant parameters. Content analysis was used to examine the research data. As a consequence of the research, it was discovered that master's theses on technology integration in education were the most popular. In the previous five years, the majority of technology integration studies in education have been conducted. The most quantitative research method was determined to be applied in the experiments. The case study was found to be the most commonly employed design among the studies analyzed in the study. It has been established that the most commonly examined participant size is between 0 and 100 people, with instructors being the most common participant group. The scale was found to be the most commonly used data collection tool in the research. In terms of data analysis, the majority of the research examined used content analysis. The information gathered was analyzed in the context of previous research. Based on literature evaluations, recommendations for future research and practitioners in the field of technology integration were offered as a consequence of the study.

Keywords: Descriptive content analyisis, Educational technologies, Technology integration 


\section{GíRiş}

Günümüzde bireyler doğdukları andan itibaren kendilerini teknolojinin içinde bulmaktadır. Bireylerin yaşamlarının her alanında teknoloji yer almaktadır (Bilgiç vd, 2011). Bu sebeple içinde bulunduğumuz çağda küresel rekabette ön plana çıkabilmek ve başarılı olmak için teknolojik becerileri de içerisine alan bazı beceriler önemli hale gelmiştir. Bu becerilere 21. yüzyıl becerileri denilmektedir. 21. yüzyıl becerileri çağımızda bireylerin sahip olması gereken becerileri ifade etmektedir. Bu becerilerle ilgili farklı sınıflandırmalar olsa da ortak olarak dikkat çeken nokta teknoloji kullanımı ile ilgili bazı becerilerin yer almasıdır. Bilgi, medya ve teknoloji becerileri, bilgi ve iletişim teknolojileri okuryazarlığı, dijital çağ okuryazarlığı gibi teknoloji ile ilgili bazı becerilerin önemine vurgu yapılmaktadır (MEB EARGED, 2011; P21, 2016; World Economic Forum, 2015). Tüm bu durumlar göz önüne alınarak var olan insan gücünün doğru şekilde kullanılabilmesi için öğrenme ortamlarında teknoloji artık bir tercih değil, zorunluluk haline gelmiştir. Bu sebeple var olan teknolojilerin öğrenme süreçlerine olabildiğince entegre edilmesi gerekmektedir (Gökoğlu, 2014). Bu gereklilikler sonucunda teknolojinin eğitime uygulanması, eğitim teknolojisi kavramını ortaya çıkmıştır. 20. yy. başlarında araç gereç kullanımı anlamına gelen eğitimde teknoloji; günümüzde bilgisayarlar, sanal eğitim ortamları gibi birçok alanı içine almaktadır (Şimşek vd., 2009).

Eğitim teknolojilerinin ortaya çıkması ve eğitime teknoloji entegrasyonunun önem kazanması, birçok ülkede olduğu gibi Türkiye'deki eğitim sistemi üzerinde de etkili olmuştur. Türkiye'de eğitimin son 10 yılına bakıldığında eğitime teknoloji entegrasyonu konusunda birçok gelişmenin yaşandığ 1 görülmektedir. Milli Eğitim Bakanlığı (MEB) 2010-2014 stratejik planında internete erişim, gelecek için eğitim projesi gibi eğitimde teknolojinin verimli kullanılması konusunda bazı projelerden bahsedilmiştir (MEB, 2009). Daha sonraki yıllarda FATİH projesi hayata geçirilmiş ve tüm okullarda teknolojiyi eğitimde etkin kullanmak hedeflenmiştir (MEB, 2015). Teknolojinin eğitimde kullanılması konusunda gelinen son noktada ise Fen, Teknoloji, Mühendislik ve Matematik eğitimi (STEM) eğitimi ortaya çıkmıştır. Bu çerçevede 2016 yılında MEB tarafından "STEM Eğitimi Raporu” yayımlanmıştır (MEB, 2016). Tüm bu gelişmeler 1şığında Türkiye'deki eğitim sistemine teknolojinin entegre edilmeye çalışıldığ söylenebilmektedir.

Eğitime teknoloji entegrasyonunun önem kazanması ve günümüzde eğitim süreçlerinde teknolojinin gittikte artan kullanımı alan yazındaki çalışmaları da etkilemiştir. İlgili alan yazın incelendiğinde eğitimde teknoloji entegrasyonu çalışmalarını inceleyen (Ersoy ve Gürgen, 2021; Demirci Güler ve Irmak, 2018; Kıranlı Güngör ve Dertli, 2021; Namdar ve Küçük, 2018), eğitimde teknoloji kapsamında STEM eğitimine yönelik çalışmaları inceleyen (Herdem \& Ünal, 2018), teknolojik pedagojik alan bilgisi çalışmalarını inceleyen (Kaleli Yılmaz, 2015), STEM eğitimi konusunda yapılan çalışmaları inceleyen (Yıldırım ve Burakgazi, 2020), eğitimde teknoloji kullanımının sürdürülebilirliği üzerine yapılan çalışmaları inceleyen (Dağhan \& Akkoyunlu, 2015) birçok araştırma tespit edilmiştir. Ancak alan yazında "eğitimde teknoloji entegrasyonu" konusunda son beş yılda Türkiye'de yayımlanan makale ve tezlerin incelendiği bir çalışmaya rastlanmamıştır. Özellikle son beş yıla ait eğitime teknoloji entegasyonu çalışmalarının incelenmesi oldukça önemlidir. Çünkü günümüzde Covid-19 sebebiyle eğitim sürecinde teknoloji daha fazla kullanılmaya başlanmış ve uzaktan eğitime zaman zaman geçiş yapılmıştır. Covid-19 salgın sürecinde eğitime teknoloji entegrasyonu konusunda ışık olması adına böyle bir çalışmaya ihtiyaç duyulmuştur. İhtiyaç çerçevesinde Türkiye'de eğitime teknoloji entegrasyonuna dair çalışmaların hangi amaç, örneklem grubu, yöntem, veri toplama aracı ve veri analiziyle yapıldığının incelenmesi, alan yazına eleştirel bir bakış açısıyla bakılması için önemli görülmektedir. Bu çerçevede çalışmanın amacı, Türkiye'de eğitimde teknoloji entegrasyonu konusunda 2015-2020 yılları arasında 
yayımlanmış makale ve tezleri inceleyerek güncel alan yazını ortaya koymak olarak belirlenmiştir. Çalışmada aşağıdaki sorulara cevap aranmıştır:

1. Çalışmaların yayın türleri ve yıllara göre dağılımı nasıldır?

2. Çalışmaların amaçlarına göre dağılımları nasıldır?

3. Çalışmaların araştırma yöntemlerine göre dağ $11 ı m ı$ nasıldır?

4. Çalışmaların araştırma desenlerine göre dağılımı nasıldır?

5. Çalışmaların katılımcı büyüklüğü açısından dağılımları nasıldır?

6. Çalışmaların katılımcı gruba göre dağılımları nasıldır?

7. Çalışmaların kullanılan veri toplama araçlarına göre dağılımı nasıldır?

8. Çalışmaların veri analiz yöntemlerine göre dağılımı nasıldır?

\section{YÖNTEM}

\subsection{Araştırma Modeli}

$\mathrm{Bu}$ araştırma nitel araştırma yöntemlerinden betimsel içerik analizine göre yapılandırılmıştır. Betimsel içerik analizinde belirli bir konuda yayımlanmış nitel ve nicel çalışmalar her yönüyle incelenmekte ve araştırma sonuçlarına dayalı olarak alan yazındaki genel eğilim belirlenmeye çalışılmaktadır (Çalık ve Sözbilir, 2014). Bu araştırmada da eğitimde teknoloji entegrasyonu ile ilgili yürütülmüş çalışmalar incelenerek 2015-2020 yılları arasında alan yazındaki genel eğilim ortaya konulmaya çalışılmaktadır.

\subsection{Veri Toplama Süreci}

Çalışma eğitimde teknoloji entegrasyonu kavramı üzerine TR Dizin ve YÖK Tez Merkezi’nde yer alan makale ve tezleri kapsamaktadır. Araştırmada "eğitim" ve "teknoloji entegrasyonu" anahtar kelimeleriyle 2015-2020 yıllarını kapsayacak şekilde tarama yapılmıştır. Alan yazın taraması 2021 Mart ayı itibariyle yapılmıştır. Elde edilen verilere göre 13 makale ve 48 tez olmak üzere toplam 61 çalışmaya ulaşılmıştır. Bu çalışmaların beş tanesinin Türkçe dışında bir dilde yazıldığı veya alan dışından olduğu tespit edildiği için araştırmadan çıkarılmıştır. Bu süreçte eğitimde teknoloji entegrasyonu konusunda iki uzman çalışmaları inceleyerek çalışmaya dahil edilip edilmemesi konusunda görüş bildirmişlerdir. Araştırmada tespit edilmiş 56 çalışma üzerinde analizler yapılmıştır. Elde edilen çalışmalar; araştırma türü, yılı, amacı, araştırma yöntemi, araştırma deseni, katılımcı büyüklüğü, katılımcılar, veri toplama aracı, veri analiz yöntemine göre incelenerek analiz edilmiştir. Çalışma derleme türünde olduğu için etik kurul izni alınmamıştır.

\subsection{Verilerin Analizi}

$\mathrm{Bu}$ çalışmada veriler nitel araştırma alt türlerinden olan içerik analizi ile analiz edilmiştir. İçerik analizinde amaç, büyük miktardaki veri setini anlamlandırmak için verileri kodlayarak, kategorize ederek anlamlandırmaktır (Fraenkel, Wallen ve Hyun, 2012). Bu araştırmada da 56 çalışmaya ait verileri anlamlandırarak genel eğilimi ortaya koymak için veriler içerik analiziyle çözümlenmiştir. 


\subsection{Veri Analizinin Güvenirliği}

Analizler araştırmacılar tarafından ayrı ayrı kodlanmıştır. Araştırmacılar tarafından kodlanan veriler arasındaki uygun yüzdesi hesaplanarak veri analizinin güvenirliği belirlenmiştir. "Uyum yüzdesi = [Görüş Birliği/ (Görüş Birliği + Görüş Ayrılığı)]” formülüne dayalı olarak uyum yüzdesi 0.86 olarak hesaplanmıştır. Bu uyum yüzdesi kodlayıcılar arasında uyum yüzdesinin yüksek olduğunu ve veri analizinin güvenilir olduğunu ifade etmektedir (Miles ve Huberman, 1994).

\section{BULGULAR}

2015-2020 yılları arasında Türkiye'de "eğitimde teknoloji entegrasyonu" konusunda yapılan tez ve makaleler analiz edilerek; araştırma türü, yıl, amaç, araştırma yöntemi, araştırma deseni, katılımcı büyüklügü̈, katılımcılar, veri toplama aracı ve veri analiz yöntemi başlıkları altında kategorilendirilmiştir.

\subsection{Yapılan Çalışmaların Yayın Türüne Göre Dağılımları}

Şekil 1'de incelenen çalışmaların türlerine göre dă̆glımı verilmiştir.

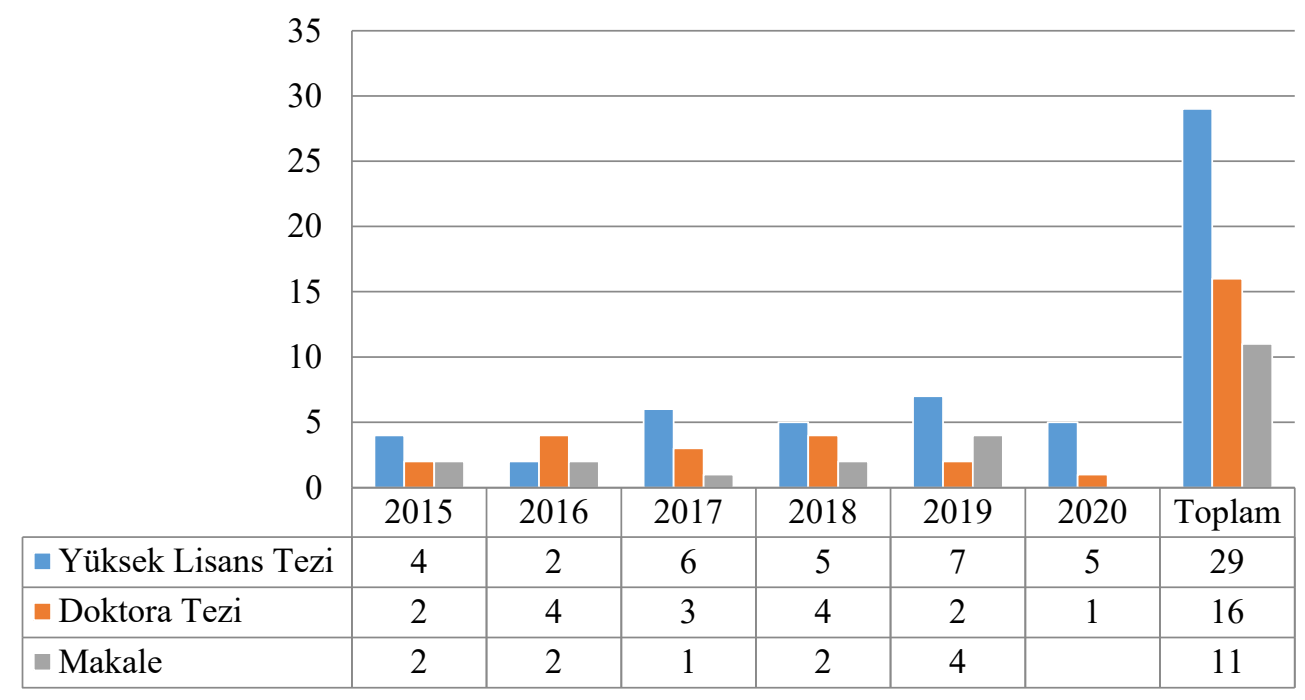

Şekil 1: Çalışmaların Yayın Türüne Göre Dă̆glımı

Şekil 1 incelendiğinde, eğitimde teknoloji entegrasyonu ile ilgili yürütülen çalışmaların çoğunun yüksek lisans tez çalışması olduğu görülmektedir. Eğitimde teknoloji entegrasyonu ile ilgili olarak yürütülen makale sayısının ise az olduğı tespit edilmiştir. Eğitimde teknoloji entegrasyonu ile ilgili çalışmaların son yıllara doğru arttığı tespit edilmiştir. Buna ilaveten en fazla çalışmanın yapıldı̆̆ yılın (f=13) çalışmayla 2019 yılına ait olduğu görülmektedir. 


\subsection{Yapılan Çalışmaların Amaçlarına Göre Dağılımları}

Şekil 2'de eğitimde teknoloji entegrasyonu ile ilgili çalışmaların amaçlarına göre dağılımlarına yer verilmiştir.

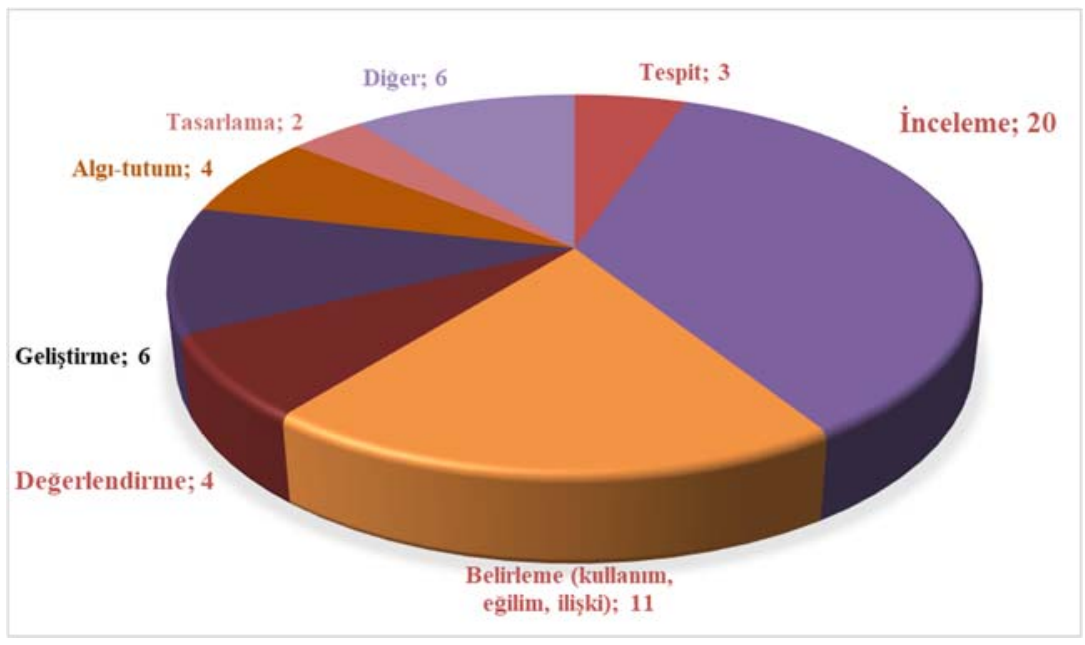

Şekil 2: Çalışmaların Amaçlarına Göre Dağılımı

Şekil 2 incelendiğinde, eğitimde teknoloji entegrasyonu ile ilgili çalışmaların genellikle inceleme üzerine yürütüldüğü görülmektedir. 11 çalışmada ise eğitimde teknoloji kullanımı, kullanımına yönelik eğilim ve ilişki belirleme amacının güdüldüğü tespit edilmiştir.

\subsection{Yapılan Çalışmaların Araştırma Yöntemlerine ve Desenlerine Göre Dağılımları}

Araştırma sonuçları incelendiğinde, eğitimde teknoloji entegrasyonu ile ilgili çalışmaların çoğunun nicel araştırma metodolojisine (f:22) uygun olarak tasarlandığ görülmektedir. 15'er çalışma ise nitel veya karma yöntem çerçevesinde planlanmıştır.

Şekil 3 incelendiğinde, çalışmaların çoğunun durum çalışması içerdiği görülmektedir. Bu durum, nitel araştırmaların çoğunun durum çalışması şeklinde yapılandırıldığını göstermektedir. Olgubilim, korelasyonel araştırma gibi araştırma desenlerini temel alan çalışmaların az olduğu tespit edilmiştir. 


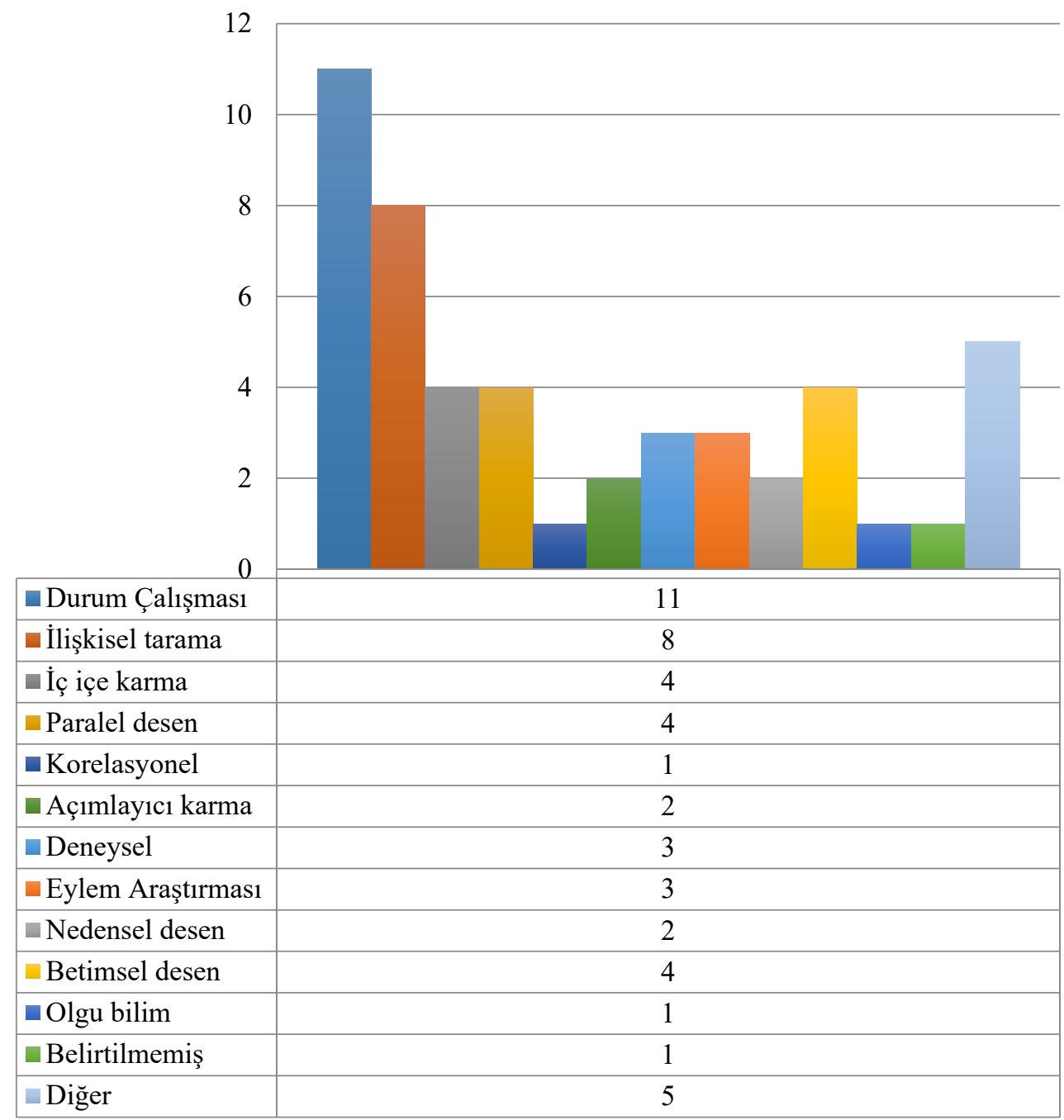

Şekil 3: Çalışmaların Araştırma Desenlerine Göre Dă̆ılımı

\subsection{Yapılan Çalışmaların Katılımcı Büyüklüğüne Göre Dağılımları}

Analiz edilen çalışmaların katılımcı büyüklüklerine göre dağılımı Şekil 4'te verilmiştir.

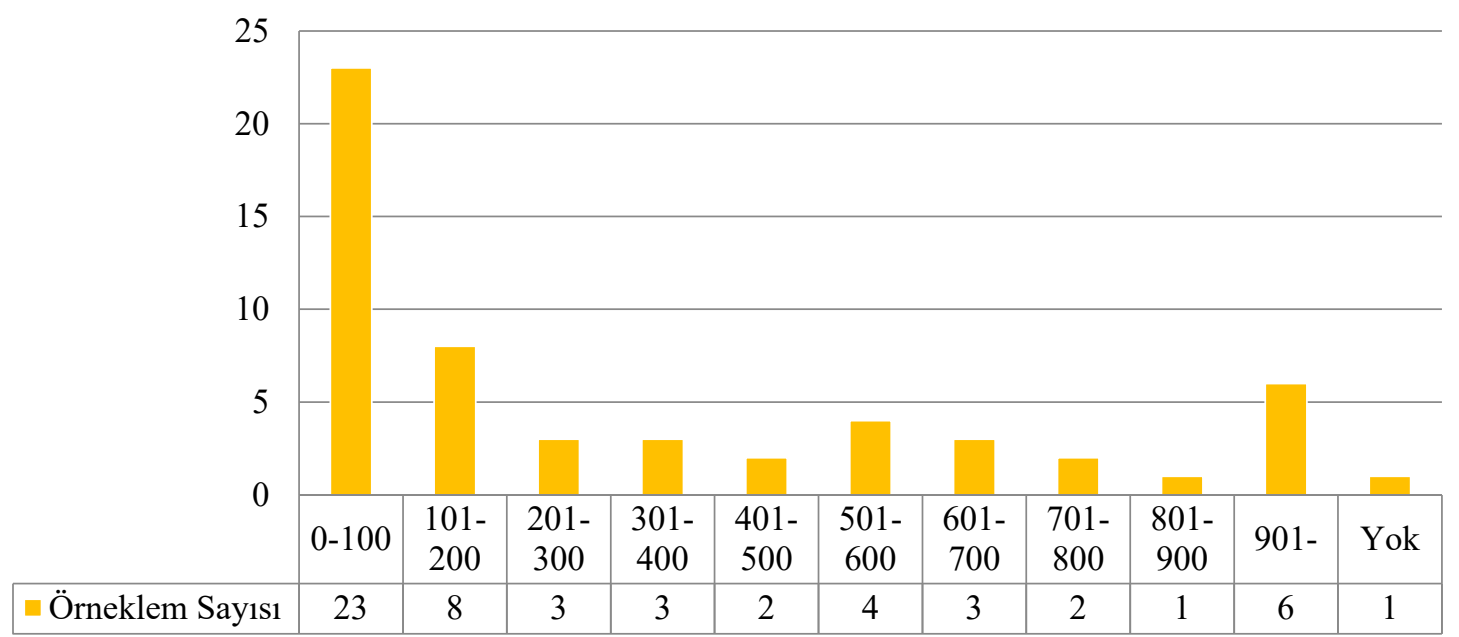

Şekil 4: Çalışmaların Katılımcı Büyüklü̈̆̈̈̈ne Göre Dağılımları 
Şekil 4'de çalışmalardaki katılımcı büyüklükleri verilmiştir. Katılımcı aralıkları dikkate alındığında çaışmaların çoğunun (f=23) katılımcı sayısının 0-100 aralığında olduğu görülmektedir. 900'ün üzerinde katılımcı sayısıyla yürütülen çalışma sayısının ise altı ile sınırlı olduğu tespit edilmiştir. Bu durumun muhtemel nedeni, büyük örneklemlere ulaşmanın daha zor olmasıdır.

\subsection{Yapılan Çalışmaların Katılımcı Gruba Göre Dağılımları}

Şekil 5'de çalışmaların katılımcı gruba göre dağılımları verilmiştir.

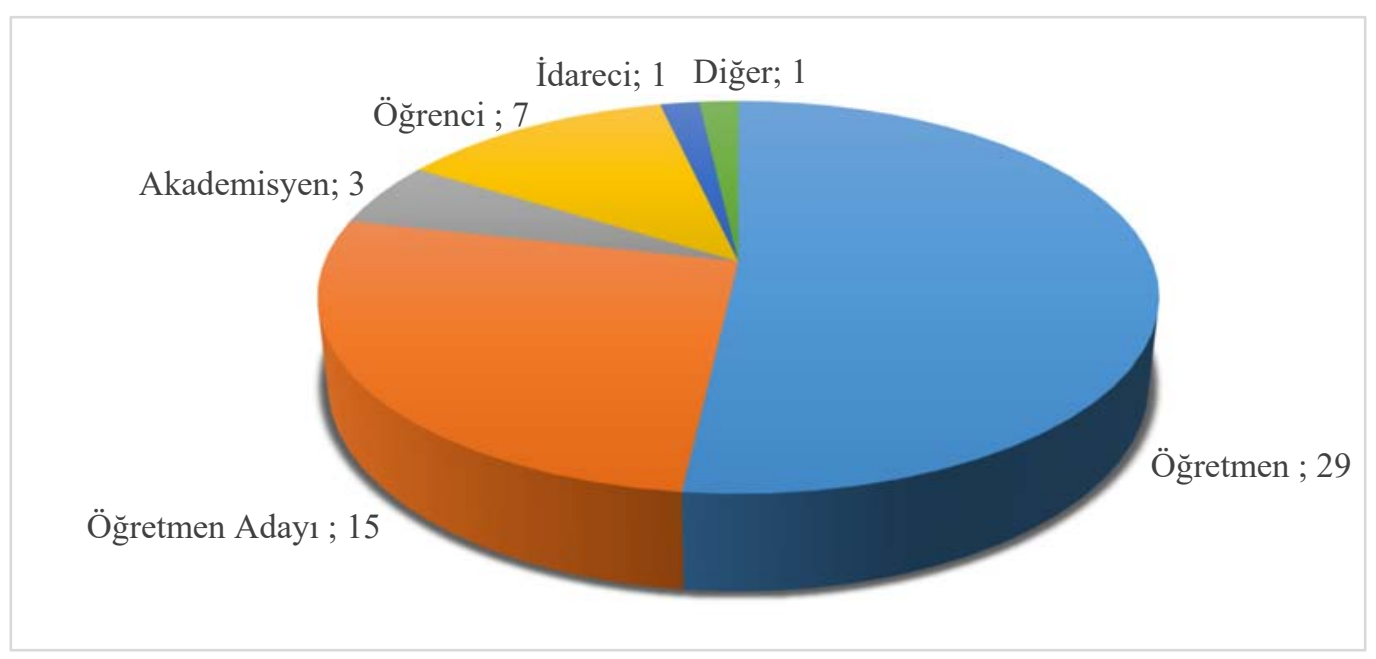

Şekil 5: Çalışmaların Katılımcı Grubuna Göre Dă̆ılımları

Şekil 5'e bakıldığında çalışmaların çoğunun $(\mathrm{f}=29)$ çalışmayla öğretmenler ile yürütüldüğü görülmektedir Eğitimde teknolojiyi daha çok öğretmenlerin kullanmasının, bu durumun muhtemel sebebi olduğu düşünülmektedir. Çalışmalar incelendiğinde, sadece bir çalışmanın idareciler ile yürütüldügü tespit edilmiştir.

\subsection{Yapılan Çalışmaların Veri Toplama Araçlarına Göre Dağılımları}

Şekil 6'da çalışmaların veri toplama araçlarına göre dağılımları verilmiştir.

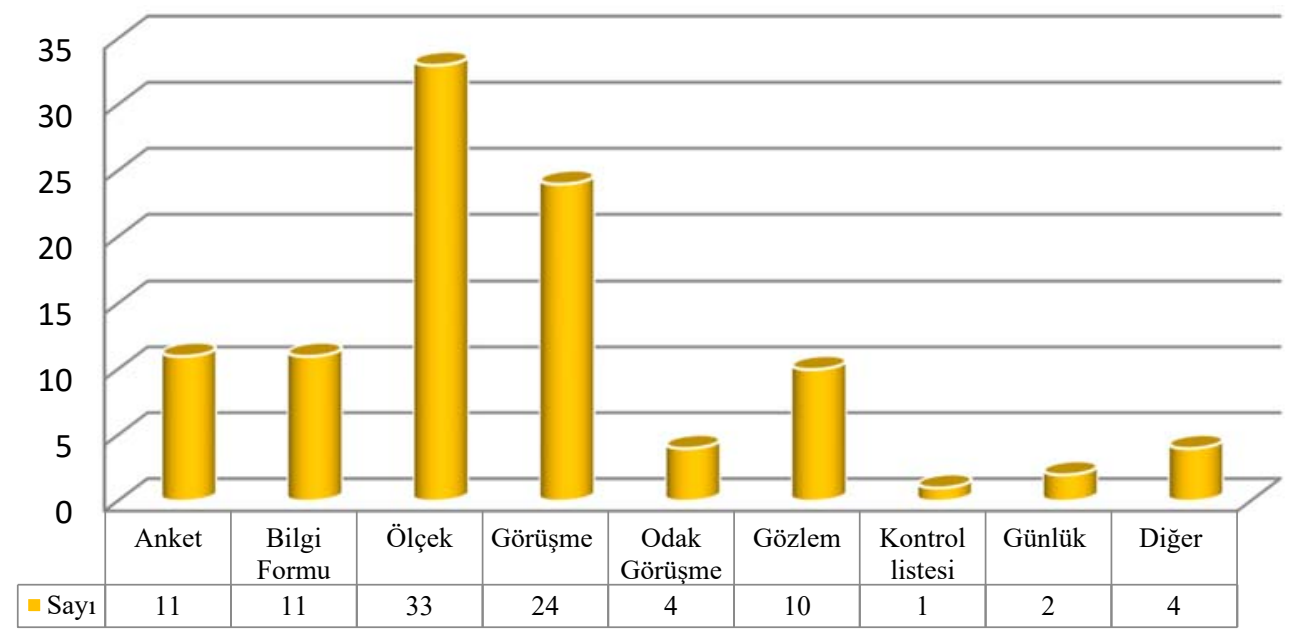

Şekil 6: Çalışmaların Veri Toplama Araçlarına Göre Dă̆ılımları

Anadolu Üniversitesi Ĕ̈itim Fakültesi Dergisi (AUJEF), 6(1), 39-55 
Şekil 6'da incelenen çalışmalarda kullanılan veri toplama araçlarının dağılımları gösterilmektedir. Bazı çalışmalarda birden fazla veri toplama aracı kullanıldığı için veri toplama araçları çalışma sayısından fazladır. İncelenen çalışmalar içerisinde en yaygın kullanılan veri toplama aracının ölçek ve görüşme formu olduğu görülmektedir. Günlük $(f=2)$ ve kontrol listelerinin ( $f=1)$, ise en az kullanılan veri toplama araçları olduğu belirlenmiştir. Bu durum, incelenen çalışmaların çoğunun nicel araştırmaya göre yapılandırıldığı bulgusuyla örtüşmektedir.

\subsection{Yapılan Çalışmaların Veri Analiz Yöntemlerine Göre Dağılımları}

Şekil 7'de incelenen çalışmalarda kullanılan veri analiz yöntemleri yer almaktadır.

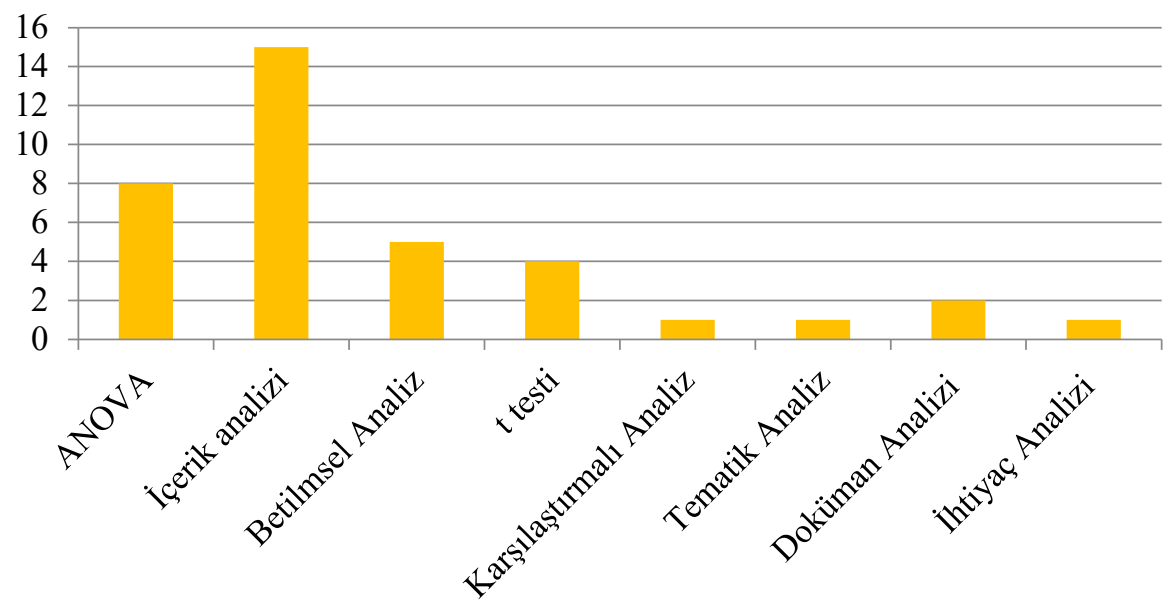

Şekil 7: Çalışmaların Veri Analizlerine Göre Dağılımları

Şekil 7 incelendiğinde, araştırmalarda en fazla kullanılan veri analiz yönteminin içerik analizi olduğu tespit edilmiştir. ANOVA ve betimsel analiz yöntemi de yine sıklıkla çalışmalarda kullanılan analiz yöntemleridir. Yapılan çalışmalarda en az ihtiyaç analizi, karşılaştırmalı analiz ve tematik analiz yöntemleri kullanılmıştır.

\section{TARTIŞMA, SONUÇ VE ÖNERILER}

Eğitimde teknoloji entegrasyonuyla ilgili 2015-2020 yılları arasında yayımlanan ulusal makale ve tezleri çeşitli açılardan incelemeyi amaçlayan bu çalışmada veriler kodlanarak analiz edilmiş ve yorumlanmıştır.

Eğitimde teknoloji entegrasyonu ile ilgili son beş yılda en çok yüksek lisans tezinin yürütüldüğü belirlenmiştir. Ayrıca eğitimde teknoloji entegrasyonuyla ilgili çalışmaların en fazla 2018 ve 2019 yıllarında gerçekleştiği tespit edilmiştir. Kıranlı Güngör ve Dertli (2021) tarafından yürütülen çalışmada da yükseköğretim kapsamında eğitim teknolojilerine yönelik yapılan lisansüstü tezlerin çoğunun yüksek lisans tezi olduğu belirlenmiştir.

Yapılan çalışmaların genellikle inceleme üzerine yürütüldüğü belirlenmiştir. Bazı çalışmalarda ise eğitimde teknoloji kullanımına yönelik eğilim ve ilişki belirleme amacının güdüldüğü tespit edilmiştir. Kaleli Yılmaz (2015) tarafından yapılan "Türkiye'deki Teknolojik Pedagojik Alan Bilgisi Çalışmalarının Analizi: Bir Meta-Sentez Çalışması” konulu çalışmada da araştırmaların konuları incelendiğinde, çalışmaların öğretmen teknolojik yeterliliklerini belirleme ve ilişkileri inceleme üzerine olduğu görülmüştür. 
Araştırmada eğitimde teknoloji entegrasyonu ile ilgili çalışmalar da daha çok nicel araştırma yönteminin kullanıldığı sonucuna ulaşılmıştır. Çalışmalar desenleri bakımından incelendiğinde ise daha çok durum çalışması ve ilişkisel tarama yapıldığı tespit edilmiştir. Kaleli Yılmaz (2015) tarafından yürütülen teknolojik pedagojik alan bilgisi ile ilgili araştırmada da incelenen nitel çalışmaların daha çok durum çalışması olduğu belirtilmiştir. Ersoy ve Gürgen (2021) tarafından yürütülen çalışmada da eğitim teknolojileri ile ilgili çalışmaların çoğunun durum çalışması deseniyle yürütüldüğü tespit edilmiştir.

Yapılan çalışmalar katılımcı büyüklüğüne göre incelendiğinde en fazla 0-100 arası katılımcı sayısı ile çalış1ldığı görülmektedir. Türkiye'de 2010-2020 yılları arasında yükseköğretimde eğitim teknolojilerine yönelik yapılan çalışmaların incelendiği bir çalışmada da çalışmaların çoğunun 0-100 arası katılımc1 sayısı ile yürütüldüğü belirlenmiştir (Kıranlı Güngör ve Dertli, 2021). Ayrıca 56 çalışmanın katılımcı gruplara göre dağılımları incelendiğinde 29 çalışmanın öğretmenler ile gerçekleştirildiği tespit edilmiştir. Ersoy ve Gürgen (2021) tarafından yürütülen çalışmada da eğitim teknolojileri ile ilgili çalışmaların çoğunun öğretmenlerle gerçekleştirildiği belirlenmiştir. Bu açıdan eğitimde teknoloji entegrasyonu konusunun daha çok öğretmenlerle çalışıldığı sonucuna ulaşılmaktadır.

Yapılan çalışmaların veri toplama araçlarına bakıldığında en fazla ölçek ve görüşmeler vasıtasıyla veri toplandığ1 belirlenmiştir. Yıldırım ve Burakgazi (2020) tarafından yapılan "Türkiye'de STEM Eğitimi Konusunda Yapılan Çalışmalar Üzerine Bir Araştırma: Meta-Sentez Çalışması” konulu araştırmada da en çok kullanılan veri toplama yönteminin benzer şekilde görüşme olduğu tespit edilmiştir. Ersoy ve Gürgen (2021) tarafından yürütülen çalışmada da eğitim teknolojileri ile ilgili çalışmaların çoğunda veri toplama aracı olarak yarı yapılandırılmış görüşme formu ve ölçek kullanıldığ 1 belirlenmiştir. Türkiye'de 2010-2020 yılları arasında yükseköğretimde eğitim teknolojilerine yönelik yapılan çalışmaların incelendiği bir çalışmada da veri toplama aracı olarak en çok ölçek kullanıldığı tespit edilmiştir (Kıranlı Güngör ve Dertli, 2021).

Eğitimde teknoloji entegrasyonuyla ilgili araştırmalardaki veri analiz yöntemi olarak en fazla içerik analizi kullanıldığı tespit edilmiştir. Benzer sonuç eğitim teknolojileri ile ilgili çalışmaları inceleyen bir araştırmada da tespit edilmiştir (Ersoy ve Gürgen, 2021). Yıldırım ve Burakgazi (2020) tarafından yapılan "Türkiye'de STEM Eğitimi Konusunda Yapılan Çalışmalar Üzerine Bir Araştırma: Meta-Sentez Çalışması" konulu araştırmada da en çok kullanılan veri analiz yönteminin içerik analizi ve betimsel analiz olduğu belirlenmiştir. Bu verilerden yola çıkarak eğitimde teknoloji ile ilgili yapılan çalışmalarda genellikle veri toplama aracı olarak yarı yapılandırılmış görüşmelerin tercih edildiği; veri analiz yöntemi olarak içerik analizinin tercih edildiği sonucuna ulaşılabilmektedir.

Araştırmadan elde edilen sonuçlar çerçevesinde bazı öneriler sunulmaktadır. İncelenen çalışmalar 2015-2020 yılını kapsayan Türkçe ve TR Dizin ve YÖK Tez'de yer alan eğitimde teknoloji entegrasyonu konusundaki 56 çalışmayla sınırlıdır. Bu bağlamda daha geniş bir zaman dilimindeki ve farklı veritabanlarındaki çalışmalar da dahil edilerek, eğitimde teknoloji entegrasyonu çalışmalarına kapsamlı bir bakış sunulabilir. Yapılan araştırma Türkiye'de yayımlanan çalışmalarla sınırlıdır, bu açıdan yurt dışında yapılan teknoloji entegrasyonuna dair çalışmalarda incelenebilir. Bu anlamda uluslararası düzeyde alan yazının genel çerçevesi sunulabilir. İncelenen çalışmalarda en fazla nicel araştırma yöntemi kullanıldığı tespit edilmiştir. Nitel araştırma yöntemi olay ve olguların daha derinlemesine incelenmesini sağladığı için nitel ve karma yöntemlerin kullanıldığı eğitimde teknoloji entegrasyonuna dair çalışmalar yürütülebilir.

\section{Araştırmacıların Katkı Oranı Beyanı}

Araştırmacılar çalışmaya eşit oranda katkı sağlamışlardır. 


\section{KAYNAKLAR}

Bilgiç, H. G., Duman, D. ve Seferoğlu, S. S. (2011). Dijital yerlilerin özellikleri ve çevrim içi ortamların tasarlanmasındaki etkileri. XIII.Akademik Bilişim Konferansı, Malatya.

Çalık, M., \& Sözbilir, M. (2014). İçerik analizinin parametreleri. Eğitim ve Bilim, 39(174).

Dağhan, G., \& Akkoyunlu, B. (2015). Eğitimde teknoloji kullanım sürdürülebilirliği üzerine yapılan çalışmalardaki genel eğilimler: Bir tematik içerik analizi çalışması. Eğitim ve Bilim, 40(178).

Demirci Güler, M. P. \& Irmak, B. (2018). Fen eğitiminde teknoloji kullanımı üzerine yapılan çalışmaların içerik analizi. Kırşehir Ĕgitim Fakültesi Dergisi, 19(3), 2473-2496.

Ersoy, M. \&. Gürgen, L. (2021). Eğitim teknolojileri ile ilgili yayımlanan makalelerin incelenmesi, E-Uluslararası Eğitim Araştırmaları Dergisi, 12(2), 2021, ss. 1-16.

Fraenkel, J. R., Wallen, N. E., \& Hyun, H. (2012). How to design and evaluate research in education. New York: McGraw Hill.

Gökoğlu, S. (2014). Sistem tabanl teknoloji liderliği modeliyle ögrenme ortamlarına teknoloji entegrasyonunun değerlendirilmesi. (Yayımlanmamış Yüksek Lisans Tezi) Karadeniz Teknik Üniversitesi Eğitim Bilimleri Enstitüsü, Trabzon.

Herdem, K., \& Ünal, İ. (2018). Analysis of studies about STEM education: A meta-synthesis study. Journal of Educational Sciences, 48(48), 145-163.

Kaleli Yılmaz, G. (2015). Türkiye'deki teknolojik pedagojik alan bilgisi çalışmalarının analizi: bir meta-sentez çalışması. Eğitim ve Bilim, 40(178).

Kıranlı Güngör, S. \& Dertli, G. (2021). Yükseköğretim kurumlarında eğitim teknolojisi üzerine yapılmış çalışmaların analizi. Journal of Computer and Education Research, 9(18), 795-830.

MEB (2009). MEB 2010-2014 Stratejik Plan. Ankara. http://sgb.meb.gov.tr/Str_yon_planlama_V2/MEBStratejikPlan.pdf (09.01.2021).

MEB (2015). Milli Eğitim Bakanlığ $2015-2019$ Stratejik Planı. Ankara. http://sgb.meb.gov.tr/meb_iys dosyalar/2015 09/10052958 10.09.2015sp17.15imzasz.pdf (09.01.2021).

MEB (2016). STEM Eğitimi Raporu. Ankara. http://yegitek.meb.gov.tr/stem_egitimi_raporu.pdf (09.01.2021).

MEB EARGED (2011). MEB 21. yüzyıl öğrenci profili. Ankara. https://www.meb.gov.tr/earged/earged/21.\%20yy og_pro.pdf (27/02/2018).

Miles, M. B. \& Huberman, A. M. (1994). Qualitative data analysis. Thousand Oaks, CA: Sage.

Namdar, B. \& Küçük, A. (2018). Fen eğitiminde teknoloji entegrasyonu çalışmalarının betimsel içerik analizi: Türkiye örneği. Mehmet Akif Ersoy Üniversitesi Eğitim Fakültesi Dergisi, (48), 355-383.

P21 (2016). Framework for 21st century learning. http://www.p21.org/storage/documents/docs/P21_framework_0816.pdf (17/06/2017).

Şimşek, A., Özdamar, N., Uysal, Ö., Kobak, K., Berk, C., Kılıçer, T. ve Çiğdem, H. (2009). İki binli yıllarda Türkiye'deki eğitim teknolojisi araştırmalarında gözlenen eğilimler. Kuram ve Uygulamada Eğitim Bilimleri Dergisi, 9(2), 941-966.

World Economic Forum (2015). New Vision for Education: Unlocking the potential of technology. Geneva.

Yıldırım, H., \& Burakgazi, S. G. (2020). Türkiye'de STEM eğitimi konusunda yapılan çalışmalar üzerine bir araştırma: Meta-sentez çalışması. Pamukkale Üniversitesi Eğitim Fakültesi Dergisi, 1-24. 


\section{EK 1-İncelenen Çalışmalar}

Aktaş, Z. (2020). Ortaokul matematik öğretmenlerinin eğitim bilişim ă̆ını kullanma durumları ve bireysel yenilikçilik özellikleri (Yayımlanmamış Yüksek Lisans Tezi). Yıldız Teknik Üniversitesi Fen Bilimleri Enstitüsü, İstanbul.

Arslan, E. (2019). Ĕ̆itim bilişim ăğ’na ilişkin okul öncesi öğretmenlerinin görüşleri (Yayımlanmamış Yüksek Lisans Tezi). Recep Tayyip Erdoğan Üniversitesi Sosyal Bilimler Enstitüsü Temel Eğitim Ana Bilim Dalı, Rize.

Artun, H. \& Günüç, S. (2016). Öğretim elemanlarının teknoloji entegrasyonu yeterliğine yönelik öğrenci algisi ölçeği: geçerlik ve güvenirlik çalışması. Yüzüncü Yıl üniversitesi Ĕ̈itim Fakültesi Dergisi, 13(1), 544-566.

Ay, Y. (2015). Öğretmenlerin teknolojik pedagojik alan bilgisi (TPAB) becerilerinin uygulama modeli bağlamında değerlendirilmesi (Yayımlanmamış Doktora Tezi). Eskişehir Osmangazi Üniversitesi, Eğitim Bilimleri Enstitüsü Eğitim Bilimleri Anabilim Dalı Eğitim Programları ve Öğretim Bilim Dalı, Eskişehir.

Aytaş, Ö. (2020). Öğretmen adaylarının bilgi ve iletişim teknolojileri ile derste teknoloji kullanımına yönelik eğilimlerinin incelenmesi (Yayımlanmamış Yüksek Lisans Tezi). Fırat ÜniversitesiEğitim Bilimleri Enstitüsü Bilgisayar ve Öğretim Teknolojileri Eğitimi Ana Bilim Dalı Bilgisayar ve Öğretim Teknolojileri Eğitimi, Elâzı ğ.

Ayvaz Tunç, Ö. (2016). Dijital teknolojiler bă̆lamında dijital öyküleme yaklaşımının güzel sanatlar eğitimine entegrasyonu (Yayımlanmamış Doktora Tezi). Ondokuz Mayıs Üniversitesi Eğitim Bilimleri Enstitüsü Güzel Sanatlar Eğitimi Anabilim Dalı Resim-İş Eğitimi Bilim Dalı, Samsun.

Babacan, T. (2016). Teknoloji destekli mikro öğretim uygulamalarının fen bilimleri öğretmen adaylarının teknolojik pedagojik alan bilgisi (TPAB) yeterlikleri üzerine etkisi (Yayımlanmamış Yüksek Lisans Tezi). Celal Bayar Üniversitesi Fen Bilimleri Enstitüsü, Manisa.

Baran, E. \& Canbazoğlu Bilici, S. (2015). Teknolojik pedagojik alan bilgisi (tpab) üzerine alanyazın incelemesi: Türkiye örneği. Hacettepe Üniversitesi Eğitim Fakültesi Dergisi, 30(1), 15-32.

Başak, M. H. (2016). Fen bilimleri öğretmenlerinin teknoloji entegrasyonunu geliştirmeye yönelik hizmet içi eğitim kurs programının hazırlanması ve etkililiğinin dĕgerlendirilmesi: fatih projesi örnĕgi (Yayımlanmamış Doktora Tezi). Karadeniz Teknik Üniversitesi Eğitim Bilimleri Enstitüsü İlköğretim Anabilim Dalı Fen Bilgisi Eğitimi Bilim Dalı, Trabzon.

Bayezit, B. (2019). Ortaokul 6. sınıf hacim konusunun ögretiminde teknoloji entegrasyonuna yönelik bir ögretim tasarımının geliştirilmesi (Yayımlanmamış Yüksek Lisans Tezi). Balıkesir Üniversitesi Fen Bilimleri Enstitüsü İlköğretim Anabilim Dalı İlköğretim Matematik Eğitimi, Balıkesir.

Bayraktar, R. (2015). Öğretmenlerin ĕgitim teknolojileri kullanım düzeylerinin belirlenmesi: ölçek geliştirme çalışması (Yayımlanmamış Yüksek Lisans Tezi). Karadeniz Teknik Üniversitesi Eğitim Bilimleri Enstitüsü Bilgisayar ve Öğretim Teknolojileri Eğitimi Ana Bilim Dalı, Trabzon.

Bilici, S. (2015). Ortä̈ğretim öğretmenlerinin teknolojik pedagojik alan bilgisi düzeylerinin etkileşimli tahta ve diğer ögretim teknolojilerini kullanma durumlarına göre incelenmesi (Yayımlanmamış Yüksek Lisans Tezi). Yüzüncü Yıl Üniversitesi Eğitim Bilimleri Enstitüsü Bilgisayar ve Öğretim Teknolojileri Eğitimi Anabilim Dalı, Van.

Bilici, S. \& Güler, Ç. (2016). Ortaöğretim öğretmenlerinin TPAB düzeylerinin öğretim teknolojilerini kullanma durumlarına göre incelenmesi. ElementaryEducation Online, 15(3).

Bodur, E. (2019). Öğretmenlerin teknoloji entegrasyonu özyeterlikleri ile etkileşimli tahtaya yönelik tutumlar arasındaki ilişki (Yayımlanmamış Yüksek Lisans Tezi). Bolu Abant İzzet Baysal Üniversitesi Eğitim Bilimleri Enstitüsü Bilgisayar ve Öğretim Teknolojileri Eğitimi Anabilim Dalı Bilgisayar ve Öğretim Teknolojileri Bilim Dalı, Bolu.

Cin, A. (2018). Ortaokul öğretmenlerinin teknolojik pedagojik alan bilgileri ile bilişim teknolojisi kullanım düzeylerinin incelenmesi mersin ili örneği (Yayımlanmamış Yüksek Lisans Tezi). Mersin Üniversitesi, Eğitim Bilimleri Enstitüsü Eğitim Bilimleri Anabilim Dalı Eğitim Programları ve Öğretim Bilim Dalı, Mersin.

Çam, S. Ş. (2018). Öğretim elemanlarının teknolojik pedagojik alan bilgilerinin geliştirilmesi için bir mesleki gelişim program önerisi (Yayımlanmamış Doktora Tezi). Gazi Üniversitesi Eğitim Bilimleri Enstitüsü Eğitim Bilimleri Ana Bilim Dalı Eğitim Programları ve Öğretim Bilim Dalı, Ankara. 
Çelik, A. (2019). Öğretmenlerin ĕgitim teknolojileri kullanım düzeylerinin belirlenmesi: Sakarya ili örneği (Yayımlanmamış Yüksek Lisans Tezi). Sakarya Üniversitesi Eğitim Bilimleri Enstitüsü Eğitim Bilimleri Anabilim Dalı Eğitim Programları ve Öğretimi Bilim Dalı, Sakarya

Değirmenci, N. (2020). Sosyal bilgiler öğretim programına yönelik mobil artırılmış gerçeklik uygulamalarının ögretmen adaylarıyla geliştirilmesi: Bir eylem araştırması (Yayımlanmamış Yüksek Lisans Tezi). Uşak Üniversitesi Lisansüstü Eğitim Enstitüsü Türkçe ve Sosyal Bilgiler Eğitimi Anabilim Dalı Sosyal Bilgiler Eğitimi Bölümü, Uşak.

Demirbağ, M. (2018). Öğretmen inançlart perspektifinden fen bilimleri ögretmenlerinin teknoloji entegrasyonu (Yayımlanmamış Doktora Tezi). Uludağ Üniversitesi Eğitim Bilimleri Enstitüsü Matematik ve Fen Bilimleri Eğitimi Anabilim Dalı Fen Bilgisi Eğitimi Bilim Dalı, Bursa.

Dikmen, C. H. (2015). Öğretmenlerin teknolojik pedagojik alan bilgileri ile ĕgitime teknoloji entegrasyonuna yönelik davranışları arasındaki ilişki: bir yapısal eşitlik modellemesi (Yayımlanmamış Yüksek Lisans Tezi). Süleyman Demirel Üniversitesi Eğitim Bilimleri Enstitüsü Bilgisayar Ve Öğretim Teknolojileri Eğitimi Anabilim Dalı, Isparta.

Döğer, M. F. (2016). Bilgisayar destekli eğitimlere katılan öğretmenlerin görüş ve deneyimlerine bağll olarak eğitimde teknoloji kullanımını etkileyen dinamikler (Yayımlanmamış Yüksek Lisans Tezi). Ankara Üniversitesi Eğitim Bilimleri Enstitüsü Yaşam Boyu Öğrenme ve Yetişkin Eğitimi Anabilim Dalı Yetişkin Eğitimi Programı, Ankara.

Dündar Öksüz, B. (2018). Fatih projesi bileşenlerinin ögretmen, idareci ve öğrenci baklş açısıyla yeniliğin yayılımı kuramı temelinde incelenmesi (Yayımlanmamış Yüksek Lisans Tezi). Karadeniz Teknik Üniversitesi Eğitim Bilimleri Enstitüsü Bilgisayar ve Öğretim Teknolojileri Eğitimi Anabilim Dalı, Trabzon.

Elkıren, Y. M. (2019). Türkçe öğretmeni adaylarının teknoloji entegrasyonu yeterlikleri ile öğretmenlik özyeterlikleri arasındaki ilişki (Yayımlanmamış Doktora Tezi). Çanakkale Onsekiz Mart Üniversitesi Eğitim Bilimleri Enstitüsü Türkçe ve Sosyal Bilimler Eğitimi Anabilim Dalı Türkçe Eğitimi Bilim Dalı, Çanakkale.

Gürfidan, H. (2017). Okul kültürü, teknoloji liderliği ve destek hizmetlerinin teknoloji entegrasyonu üzerindeki rolü: bir yapısal eşitlik modelleme çalışması (Yayımlanmamış Yüksek Lisans Tezi). Süleyman Demirel Üniversitesi Eğitim Bilimleri Enstitüsü Bilgisayar ve Öğretim Teknolojileri Eğitimi Anabilim Dalı, Isparta.

İlkay, N. (2017). Okul öncesi ögretmen adaylarının teknolojik pedagojik alan bilgilerine yönelik özyeterliklerinin incelenmesi (Sakarya Üniversitesi örneği) (Yayımlanmamış Yüksek Lisans Tezi). Sakarya Üniversitesi Eğitim Bilimleri Enstitüsü Eğitim Bilimleri Anabilim Dalı Yükseköğretim Araştırmaları Bilim Dalı, Sakarya.

Kaleci, F. (2018). Bilgi ve iletişim teknolojilerinin matematik eğitimi sürecine entegrasyonuna yönelik hizmet içi eğitim programı uygulaması ve etkililiği (Yayımlanmamış Doktora Tezi). Necmettin Erbakan Üniversitesi Eğitim Bilimleri Enstitüsü İlköğretim Anabilim Dalı Matematik Eğitimi Bilim Dalı, Konya.

Kalkan, Ö. (2019). Teknoloji entegrasyonuna yönelik düzenlenen hizmet içi eğitimlerin etkililiği konusunda ögretmen ve akademisyenlerin önerileri (Yayımlanmamış Yüksek Lisans Tezi). Trabzon Üniversitesi Lisansüstü Eğitim Enstitüsü Bilgisayar ve Öğretim Teknolojileri Eğitimi Anabilim Dalı, Trabzon.

Kartal, B. (2019). Öğretmen adaylarının eğitim teknolojilerine ilişkin tutumlarının, öz yeterliklerinin ve kullanım amaçlarının incelenmesi. Yüzüncü Yıl Üniversitesi Eğitim Fakültesi Dergisi, 16(1), 436-463.

Kaya, M. F. (2018). 4. sınıf ögrencilerinin temel dil becerilerinin geliştirilmesine yönelik tersyüz sınıf modelinin uygulanması (Yayımlanmamış Doktora Tezi). Eskişehir Osmangazi Üniversitesi Eğitim Bilimleri Enstitüsü Eğitim Bilimleri Anabilim Dalı Eğitim Programları ve Öğretim Bilim Dalı, Eskişehir.

Kaya, M. T. (2019). Sosyal bilgiler ögretmenlerinin teknopedagojik ĕgitim yeterlilikleri ve akıllı tahta özyeterliliklerinin incelenmesi: Afyonkarahisar örneği (Yayımlanmamış Doktora Tezi). Afyon Kocatepe Üniversitesi Sosyal Bilimler Enstitüsü Türkçe ve Sosyal Bilimler Eğitimi Anabilim Dalı, Afyon.

Kaya, R. (2020). Eğitim fakültesi ögrencilerinin teknoloji entegrasyonu öz-yeterlik alglları ile dijital yeterlik seviyeleri arasındaki ilişkisinin incelenmesi (Yayımlanmamış Yüksek Lisans Tezi). Balıkesir Üniversitesi Sosyal Bilimler Enstitüsü Eğitim Bilimleri Anabilim Dalı Eğitim Programları ve Öğretim Bilim Dalı, Balıkesir. 
Keleş, E. \&Güntepe, E. T. (2018). Eğitim fakültesi öğretim elemanlarının teknolojiyi öğrenme-öğretme sürecine entegrasyonu. Sakarya UniversityJournal of Education, 8(3), 142-157.

Kırındı, T. \& Durmuş, G. (2019). Fen bilimleri öğretmenlerinin teknolojik pedagojik alan bilgilerinin incelenmesi. Ahi Evran Üniversitesi Kırşehir Ë̆itim Fakültesi Dergisi, 20(3), 1340-1375.

Koyunkaya, M. Y.\&Taşdan, B. T. (2019). Matematik öğretmen adaylarının ders planlarının teknoloji entegrasyonu açısından değerlendirilmesi. Eskişehir Osmangazi Üniversitesi Sosyal Bilimler Dergisi, 20, 1137-1166.

Kuşkaya Mumcu, F. \& Koçak Usluel, Y. (2015). Öğretmen adaylarının bit entegrasyonuna hazır olmalarını sağlamada bir ağsal öğrenme sürecinin tasarlanması. Ankara Üniversitesi Ĕ̌gitim Bilimleri Fakültesi Dergisi, 48(1), 19-47.

Moyenga, M. (2018). Öğretmen adaylarının ĕgitiminde teknolojik yeterlikler, inançlar ve engeller (Burkina faso örneği) (Yayımlanmamış Yüksek Lisans Tezi). Necmettin Erbakan Üniversitesi Eğitim Bilimleri Enstitüsü Bilgisayar ve Öğretim Teknolojileri Eğitimi Ana Bilim Dalı Bilgisayar ve Öğretim Teknolojileri Eğitimi Bilim Dal, Konya.

Okur, S. (2020). Sınıf öğretmenlerinin ĕgitim teknolojisi standartlarına ilişkin deneyimleri: durum çalışması (Yayımlanmamış Yüksek Lisans Tezi). Mersin Üniversitesi Eğitim Bilimleri Enstitüsü Bilgisayar ve Öğretim Teknolojileri Eğitimi Anabilim Dalı, Mersin.

Ormancı, Ü. \& Çepni, S. (2019). Rehberli araştırma-sorgulama yaklaşımına uygun web destekli fen materyali geliştirilmesi: Kemikler. Araştırma Temelli Etkinlik Dergisi, 9(2), 96-108.

Özbay, U. (2016). Fen bilimleri ögretmenlerinin mobil uygulamaları kullanım durumlarl ve fen eğitimi sürecindeki kullanımı hakkındaki görüş̧leri (Yayımlanmamış Yüksek Lisans Tezi). Aksaray Üniversitesi Fen Bilimleri Enstitüsü Matematik ve Fen Bilimleri Eğitimi Anabilim Dalı Fen Bilgisi Eğitimi Bilim Dalı, Aksaray.

Sarıtepeci, M. (2016). Dijital hikâye anlatım yönteminin sosyal bilgiler dersinde etkililiğinin incelenmesi (Yayımlanmamış Doktora Tezi). Gazi Üniversitesi Eğitim Bilimleri Enstitüsü Bilgisayar ve Öğretim Teknolojileri Anabilim Dalı, Ankara.

Sevimli, N. E. (2020). Istatistiksel kavramların teknoloji kullanımıla öğretimine yönelik tasarlanan bir öğretim modülünün etkililiğinin incelenmesi (Yayımlanmamış Doktora Tezi). Marmara Üniversitesi Eğitim Bilimleri Enstitüsü Matematik ve Fen Bilimleri Eğitimi Ana Bilim Dalı Matematik Öğretmenliği Bilim Dalı, İstanbul.

Sezer, B. (2016). Teknoloji yoğun ortamlar için bir elektronik performans destek sisteminin tasarımı (Yayımlanmamış Doktora Tezi). Ankara Üniversitesi Eğitim Bilimleri Enstitüsü Bilgisayar ve Öğretim Teknolojileri Eğitimi Anabilim Dalı Eğitim Teknolojisi Programı, Ankara.

Sola Özgüç, C. (2015). Zihin yetersizliği olan ortaokul ögrrencilerinin bulunduğu bir sınıfta öğretim etkinliklerinin teknoloji desteği ile geliştirilmesi: bir eylem araştırması (Yayımlanmamış Doktora Tezi). Eskişehir Anadolu ÜniversitesiEğitim Bilimleri EnstitüsüÖzel Eğitim Ana Bilim Dalı, Eskişehir.

Şentürk, M. L. (2017). Fizik öğretmenlerinin kuvvet ve hareket konusunda animasyon \& simülasyon-tpab düzeyleri: sınıf içi bütüncül çoklu durum çalışması (Yayımlanmamış Doktora Tezi). Gazi Üniversitesi Eğitim Bilimleri Enstitüsü İlköğretim Anabilim Dalı, Ankara.

Şimşek, Ö., Bars, M. \& Zengin, Y. (2017). Matematik öğretiminin ölçme ve değerlendirme sürecinde bilgi ve iletişim teknolojilerinin kullanımı. Uluslararası Ĕ̆itim Programları ve Öğretim Çalışmaları Dergisi, 7(13), 189-207.

Taş, M (2017). Tarih öğretmenlerinin eğitimde teknoloji entegrasyonuna ilişkin algl ve görüşlerinin incelenmesi (Yayımlanmamış Yüksek Lisans Tezi). Ankara Üniversitesi Eğitim Bilimleri Enstitüsü İlköğretim Anabilim Dalı Sosyal Bilgiler Eğitimi Programı, Ankara.

Tenkoğlu, H. (2017). Fen bilimleri dersinde teknoloji entegrasyon matrisi modelinin öğrencilerin teknoloji standartları, yansıtıcı düşünme becerileri ve akademik başarılarına etkisi (Yayımlanmamış Yüksek Lisans Tezi). Amasya Üniversitesi Fen Bilimler Enstitüsü İlköğretim Ana Bilim Dalı Fen Bilgisi Eğitimi Bilim Dal1, Amasya.

Tonbuloğlu, İ. (2017). Öğretmen adaylarının mobil teknolojileri ögretim amaçlı kullanım kabullerinin incelenmesi (Yayımlanmamış Doktora Tezi). Sakarya Üniversitesi Eğitim Bilimleri Enstitüsü Bilgisayar ve Öğretim Teknolojileri Eğitimi Anabilim Dalı, Sakarya. 
Tosuntaş, Ş. B. (2017). Öğretmenlerin etkileşimli tahta kullanımına etki eden faktörler ve öğretmen performansına etkisi (Yayımlanmamış Doktora Tezi). Eskişehir Osmangazi Üniversitesi Eğitim Bilimleri Enstitüsü Eğitim Bilimleri Anabilim Dalı Eğitim Programları ve Öğretim Bilim Dalı, Eskişehir.

Turan Güntepe, E. (2015). Eğitim fakültesindeki öğretim elemanlarının eş merkezli halka modeline göre teknoloji entegrasyon sürecini değerlendirme (Yayımlanmamış Yüksek Lisans Tezi). Karadeniz Teknik Üniversitesi Eğitim Bilimleri Enstitüsü Bilgisayar ve Öğretim Teknolojileri Eğitimi Anabilim Dalı, Trabzon.

Uçar, A. (2017). Öğretmenlerin sınıf yönetimi algllarının teknoloji destekli işlenen derslerde çeşitli değişkenler açısından incelenmesi (Yayımlanmamış Yüksek Lisans Tezi). Gazi ÜniversitesiEğitim Bilimleri Enstitüsü Bilgisayar ve Öğretim Teknolojileri Eğitimi Ana Bilim Dalı, Ankara.

Uğur, B. (2019). Teknolojinin öğrenme-öğretme süreçlerine entegrasyonuna ilişkin tasarlanan çevrimiçi bir derse yönelik öğretmen görüşleri (Yayımlanmamış Yüksek Lisans Tezi). Hacettepe Üniversitesi Eğitim Bilimleri Enstitüsü Bilgisayar ve Öğretim Teknolojileri Eğitimi Ana Bilim Dalı, Ankara.

Uyduran, M. (2018). Sınıf öğretmenlerinin bilişim teknolojilerini kullanım düzeylerinin farklı değişkenler açısından incelenmesi (Yayımlanmamış Yüksek Lisans Tezi). Gaziantep Üniversitesi Eğitim Bilimleri Enstitüsü Eğitim Bilimleri Ana Bilim Dalı, Gaziantep.

Üzel, D. \& Mert Uyangör, S. (2018). Eğitim fakültesi matematatik öğretmen adayları ve pedagojik formasyon eğitimi sertifika programı adaylarının teknolojik pedagojik alan bilgilerinin karşılaştırılması. Electronic TurkishStudies, 13(27).

Yılmaz, O. (2018). Ĕgitimde teknoloji entegrasyonu sürecinde okul yöneticilerinin öğretimsel liderlik yeterliliklerine yönelik ögretmen görüşleri (İstanbul ili Başakşehir ilçesi örneği) (Yayımlanmamış Yüksek Lisans Tezi). Trakya Üniversitesi Sosyal Bilimler Enstitüsü Eğitim Bilimleri Anabilim Dalı Eğitim Yönetimi, Teftişi, Planlaması ve Ekonomisi Bilim Dalı, Edirne.

Yılmaz, O. (2019). Öğretmenlerin bit entegrasyon yaklaşımları, teknoloji entegrasyonuna yönelik öz-yeterlik algısı ve bireysel yenilikçilik özellikleri arasındaki ilişkiler (Yayımlanmamış Yüksek Lisans Tezi). Necmettin Erbakan Üniversitesi Eğitim Bilimleri Enstitüsü Bilgisayar ve Öğretim Teknolojileri Eğitimi Anabilim Dalı Bilgisayar ve Öğretim Teknolojileri Eğitimi Bilim Dalı, Konya. 


\section{EXTENDED ABSTRACT}

In terms of variables, this study intends to expose the comparable and dissimilar characteristics of papers and theses published in the field of education between 2015 and 2020 on technology integration in Turkey.

TR Dizin and YOK Thesis Center publications and theses on the notion of technology integration are included in the study. A search was made using the phrase "technology integration" in the field of education, with the requirement that it spans the years 2015-2020. According to the information gathered, a total of 61 results were obtained, including 13 articles and 48 theses, however, it was decided that 56 of them were subject to technology integration with educational sciences content in the Turkish language, with authorization to publish. Between the years 2015 and 2020, content analysis was utilized to assess theses and articles that investigated the notion of technology integration.

According to reports, the majority of the technology integration studies took place in 2018 and 2019. Considering the distribution of the studies according to the fields of study, it was concluded that the studies on examination and determination of the situation were made the most. In addition, it was determined that ( $\mathrm{f}=11$ ) studies were conducted on "use, tendency, and relationship determination", and $(\mathrm{f}=6)$ studies were conducted on "development". There are also studies on "other" subjects $(\mathrm{f}=6)$, "perception-attitude" ( $(\mathrm{f}=4)$ and "evaluation" ( $\mathrm{f}=4)$. The least targeted subject was "detection" ( $\mathrm{f}=3)$ and "design" ( $\mathrm{f}=2$ ) purposes. The majority of studies on technology integration in education have used quantitative research methods. The approach was stated in the majority of the research, and some were undertaken for module creation and design. When we look at the studies in qualitative research methods $(\mathrm{f}=11)$, it is seen that the most preferred one by the researchers is the case study. When looking at the quantitative researches $(\mathrm{f}=8)$, it can be said that the most preferred one with the study is relational screening. When we look at the studies examined, it is seen that working with teacher candidates ( $\mathrm{f}=15)$, working with students $(\mathrm{f}=7)$, and academics $(\mathrm{f}=3)$. The least amount of work is manager $(\mathrm{f}=1)$ and other $(\mathrm{f}=1)$ work. Considering the participant ranges $(\mathrm{f}=23)$, it is seen that the most frequently selected number of participants in the study is in the range of $0-100$. Then, it is seen that there is a range of 101-200 participants with the study $(\mathrm{f}=8)$ and there are studies with 901-participants with the study $(\mathrm{f}=6)$. The least number of participants $(\mathrm{f}=1)$ is not specified and belongs to category 801-900. When the data collection tools of the studies were examined, it was determined that the scales and interviews were mostly used. It was determined that diary $(\mathrm{f}=2)$, checklist $(\mathrm{f}=1)$, focus interview $(\mathrm{f}=4)$ and other methods $(\mathrm{f}=4)$ were used the least. It is seen that the data collection tools used and the method shows parallelism. The most used data analysis method in the researches examined ; content analysis was found. ANOVA and descriptive analysis methods are also frequently used analysis methods in studies. In the studies carried out, there is at least needs analysis, comparative analysis, and thematic analysis.

In the study conducted by Kranl Güngör and Dertli (2021), it was established that the majority of postgraduate theses on educational technology within the purview of higher education are master theses. In a study conducted by Ersoy and Gürgen (2021), it was discovered that the majority of educational technology studies followed a case study format. The majority of educational technology studies were conducted with instructors, according to the same study. In this regard, it is concluded that teachers are the primary participant on the subject of technology integration in education. In a study examining the 
studies on educational technologies in higher education between the years 2010-2020 in Turkey, it was determined that the scale was used the most as a data collection tool (Kıranlı Güngör and Dertli, 2021).

Within the context of the research findings, some recommendations are offered. The works looked at were confined to 56 studies on technology integration in education that were included in the Turkish and TR Index and YOK Thesis from 2015 to 2020. In this context, a full picture of technology integration studies in education can be offered by combining studies from different periods and databases. The research is limited to studies published in Turkey ; nevertheless, it can be compared to studies on technology integration conducted elsewhere. In this way, the international literature's general framework might be described. The most quantitative research method was found to be applied in the studies reviewed. Since the qualitative research method provides a more in-depth examination of events and phenomena, studies on technology integration can be carried out in education where qualitative and mixed methods are used. 